\title{
Synthesis of carbohydrate-derived $(Z)$-vinyl halides and silanes: samarium-promoted stereoselective 1,2-elimination on sugar-derived $\alpha$-halomethylcarbinol acetates
}

\author{
Martín Soto $^{\mathrm{a}}$, Raquel G. Soengas ${ }^{\mathrm{b}, \mathrm{c}}$, Artur M. S. Silva ${ }^{\mathrm{b}}$, Vicente Gotor-Fernández ${ }^{\mathrm{a}}$, Humberto Rodríguez- \\ Solla ${ }^{\mathrm{a}, *}$ \\ ${ }^{a}$ Dept. of Organic and Inorganic Chemistry, University of Oviedo, Julián Clavería 8, 33006, Oviedo (Spain) \\ ${ }^{b}$ Dept. of Chemistry \& QOPNA, University of Aveiro, 3810-193, Aveiro (Portugal) \\ ${ }^{c}$ Dept. of Chemistry \& Physics, University of Almería, 04120, Almería (Spain)
}

\section{ARTICLE INFO}

\section{Article history:}

Received

Received in revised form

Accepted

Available online

\section{Keywords:}

carbohydrates

elimination

samarium

silanes

Sonogashira reaction

stereoselectivity

vinyl halides

\section{ABSTRACT}

A general and highly selective method for the synthesis of carbohydrate-derived ( $Z$ )vinyl halides and silanes is described. This reaction takes place through a $\beta$-elimination process of sugar-derived $\alpha$-halomethylcarbinol acetates promoted by samarium diiodide. Starting materials have been easily prepared in two steps consisting in an initial addition of halomethyllithium compounds to the corresponding galactose-derived aldehyde, followed by acetylation. A mechanism that explains both the formation of (Z)-vinyl derivatives and its selectivity is proposed. Finally, the synthetic usefulness of these compounds has been applied in cross-coupling reactions with ethynyl benzene towards the formation of selected enyne derivatives.

2009 Elsevier Ltd. All rights reserved.

\section{Introduction}

Halovinyl carbohydrate derivatives are compounds of great interest on account of their usefulness as synthetic intermediates. ${ }^{1}$ The presence of the haloalkenyl moiety makes halovinyl sugars ideal precursors for palladium catalyzed cross-coupling reactions, which could be exploited for the introduction of new substituents, the elongation of the sugar chain and the formation of $C$ glycosides. Accordingly, these derivatives have been used as intermediates in the preparation of natural products, ${ }^{2} C$ glycosides, ${ }^{3}$ polyols ${ }^{4}$ and nucleosides. ${ }^{5}$

Despite halovinyl sugars have proven to be extremely effective tools for the elongation of the sugar chain and the preparation of very diverse carbohydrate derivatives, this topic has not been extensively investigated. This may be due to the limited access to these intermediates in enantiopure form.

Although various synthetic precursors have been used for the synthesis of sugar-derived halovinyls, one of the most common methods is still the halogenation-reduction of alkynes. Thus, sugar-derived halovinyls have been mostly prepared from sugar acetylenes via halogenation and diimide cis-hydrogenation. ${ }^{2 \mathrm{~b}, 3} \mathrm{On}$ the other hand, uridine-derived halovinyl compounds have been synthesized from vinyl sulfones via vinyltin intermediates. ${ }^{6}$ Takai's procedure has been also applied for the preparation of these derivatives. ${ }^{7}$ In this sense, it has been reported that treating a sugar-derived aldehyde with iodoform and chromium dichloride, afforded $E / Z$ mixtures of the corresponding iodoalkenes in moderate yields. ${ }^{2 a, 8}$ Finally, León and co-workers reported the $\mathrm{CrCl}_{2}$-promoted reductive elimination of gem-dihalo compounds to obtain alkenyl halides in good yields but with poor stereoselectivity. ${ }^{9}$

In this context, the development of a novel and efficient procedure to obtain sugar-derived halovinyl compounds in good yields and stereoselectivities would be still desirable. Related to that, we have recently described a novel, efficient and general methodology for the indium-promoted reduction of gemdibromides to afford $(E)$-vinyl bromides in ionic liquid media under ohmic heating. ${ }^{10}$ This procedure is very effective for the preparation of sugar-derived $(E)$-bromoalkenes, which on Pdcatalyzed cross-coupling reactions (Heck, Stille, Suzuki, Kumada and Sonogashira) afford a wide set of sugar alkenes, dienes and enynes.

Previous work in our laboratory has demonstrated the utility of samarium diiodide to promote stereoselective processes directed towards the synthesis of $(Z)$-unsaturated systems. Thus, we have already reported the synthesis of $(Z)$-allyl ${ }^{11}$ and $(Z)$-vinylsilanes, ${ }^{12}$ (Z)- $\beta, \gamma$-unsaturated nitriles, ${ }^{13}(Z)$-alkenes, ${ }^{14}(Z)$-vinyl halides ${ }^{15}$ and (Z)- $\alpha, \beta$-unsaturated amides. $^{16}$ Herein, we describe a 
complementary methodology to the previous work reported by our group for the synthesis of $(E)$-vinyl halides. ${ }^{10}$ These initial results prompted us to test the application of samarium diiodide as a versatile reagent for an efficient, simple, and rapid synthesis of carbohydrate-derived ( $Z$ )-haloalkenes from sugar-aldehydes $\mathbf{1}$ through a stereoselective 1,2-elimination on their corresponding $\alpha$-halomethylcarbinol acetates 2 (Scheme 1).

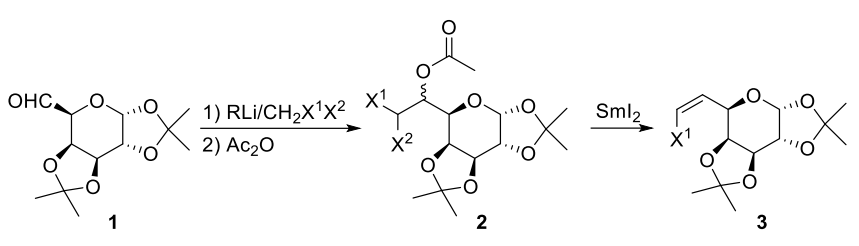

Scheme 1. Synthetic procedure for the preparation of carbohydrate derived (Z)-vinyl halides and silanes $\mathbf{3}$.

\section{Results and discussion}

While the importance of polyhalogenated sugars is obvious, stereocontrolled introduction of the polyhalomethyl group in a carbohydrate moiety is not widely achievable. One of the most straightforward pathways to generate $\alpha$-polyhalomethylcarbinols is the nucleophilic addition of organolithium compounds to aldehydes. The potential difficulties, when applying this approach to sugar aldehydes, rely on the sensitivity of sugar aldehydes to strong bases and the lack of stereocontrol during the addition process. Moreover, organolithium reagents are rather unstable even at low temperature. Accordingly, we have envisioned a strategy for the preparation of sugar $\alpha$-halomethyl carbinols based on the in situ generation of halomethyllithium. Thus, on slow addition of the base over a solution of aldehyde in the presence of an excess of the corresponding dihalomethane or chloromethyltrimethylsilane, the kinetically generated dihalomethyllithium species would react with the aldehyde before side reactions and decomposition take place.

In our preliminary studies, we screened a variety of conditions for the stereoselective addition of diiodomethyllithium to the galactose-derived aldehyde $\mathbf{1}$ to generate the diiodomethylcarbinol intermediate $\mathbf{4 a}$, paying special attention to the influence of different bases, solvents and temperatures (Table 1).

Table 1. Screening for diiodomethyllithium addition to sugar aldehyde $\mathbf{1 .}$

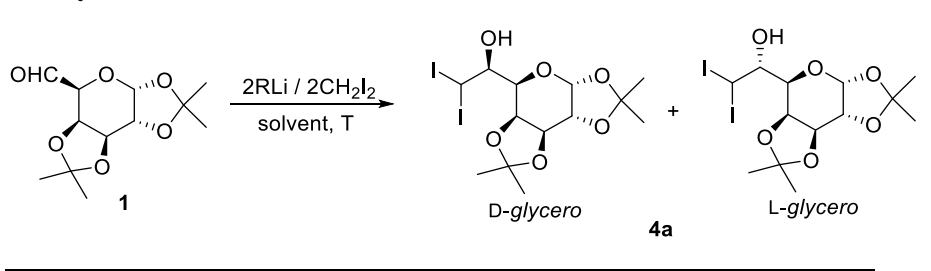

\begin{tabular}{cccccc}
\hline Entry & $\mathrm{RLi}$ & Solvent & $\mathrm{T}\left({ }^{\circ} \mathrm{C}\right)$ & ${\text { D-/L- } \text { glycero }^{\mathrm{a}}}$ & ${\text { Yield }(\%)^{\mathrm{b}}}^{2}$ \\
\hline 1 & $\mathrm{TMPLi}$ & $\mathrm{THF}$ & -78 & $82 / 18$ & 64 \\
2 & $\mathrm{HMDSLi}$ & $\mathrm{THF}$ & -78 & $79 / 21$ & 70 \\
3 & $n-\mathrm{BuLi}$ & $\mathrm{THF}$ & -78 & $74 / 26$ & 28 \\
4 & $i-\mathrm{Pr}_{2} \mathrm{NLi}$ & $\mathrm{THF}$ & -78 & $82 / 18$ & 86 \\
5 & $i-\mathrm{Pr}_{2} \mathrm{NLi}$ & $\mathrm{THF}$ & -30 & $75 / 25$ & 55 \\
6 & $i-\mathrm{Pr}_{2} \mathrm{NLi}$ & $\mathrm{Et}{ }_{2} \mathrm{O}$ & -78 & $63 / 37$ & 64 \\
\hline
\end{tabular}

${ }^{\mathrm{a}} \mathrm{D}$-/L-glycero ratio was determined by ${ }^{1} \mathrm{H}$ NMR analysis of the crude reaction mixture. ${ }^{\mathrm{b}}$ Isolated yield of compound $\mathbf{4 a}$ after column chromatography relative to sugar-aldehyde

Firstly, it was found that the use of TMPLi (TMP $=2,2,6,6$ tetramethylpiperidine) as base in THF at $-78^{\circ} \mathrm{C}$ conducted to good selectivity and yield (Table 1, entry 1). HMDSLi gave similar results (Table 1, entry 2), while $n$-BuLi provided low yields of the desired diiodo compound (Table 1, entry 3). In this case, the epoxide derived from the iodomethylation of the sugar-aldehyde has been obtained as the main product. ${ }^{17}$ On the other hand, LDA in THF at $-78{ }^{\circ} \mathrm{C}$ afforded derivative $4 a$ in $86 \%$ yield and good selectivity (82/18) (Table 1, entry 4). Rising the temperature up to $-30{ }^{\circ} \mathrm{C}$ caused a steep decrease in the yield (Table 1 , entry 5). Finally, $\mathrm{Et}_{2} \mathrm{O}$ was employed as solvent affording similar yield but lower stereoselectivity (Table 1 , entry 6). The configuration obtained after the addition of diiodomethyllithium to aldehyde $\mathbf{1}$ could be easily explained through a Felkin-Ahn model. Thus, diiodomethyllithium would attack the si face giving preferentially D-glycero stereoisomer through a model similar to that used to explain the stereoselectivity observed in the addition of nitronates, ${ }^{18}$ methyllithium, ${ }^{19}$ or halomethyllithium ${ }^{20}$ to sugarderived carbonyl compounds.

LDA in THF at $-78^{\circ} \mathrm{C}$ (Table 1, entry 4) showed the best results in terms of yield and selectivity, and these conditions were taken forward. Then, the scope of the reaction was investigated using diiodo-, dibromo-, chloroiodomethyllithium, and (chlorolithiomethyl)trimethylsilane. In all cases, the corresponding addition products 4a-d were obtained in good yields and moderate selectivities for the D-glycero isomer (Table 2).

Table 2. Synthesis of halomethyl carbinols 4 .

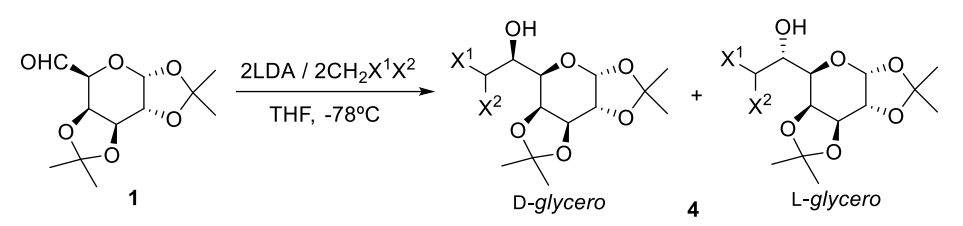

\begin{tabular}{cccccc}
\hline Entry & $\mathbf{4}$ & $\mathrm{X}^{1}$ & $\mathrm{X}^{2}$ & D-/L-glycero $^{\mathrm{a}}$ & Yield (\%) $^{\mathrm{b}}$ \\
\hline 1 & $\mathbf{4 a}$ & $\mathrm{I}$ & $\mathrm{I}$ & $82 / 18$ & 86 \\
2 & $\mathbf{4 b}$ & $\mathrm{Cl}$ & $\mathrm{I}$ & $66 / 34$ & 64 \\
3 & $\mathbf{4 c}$ & $\mathrm{Br}$ & $\mathrm{Br}$ & $84 / 16$ & 79 \\
4 & $\mathbf{4 d}$ & $\mathrm{SiMe}_{3}$ & $\mathrm{Cl}$ & $67 / 33$ & 70 \\
\hline
\end{tabular}

${ }^{a} \mathrm{D}-/ \mathrm{L}$-glycero ratio was determined by ${ }^{1} \mathrm{H}$ NMR analysis on the crude reaction mixture. ${ }^{\mathrm{b}}$ Isolated yield of compounds $\mathbf{4}$ after column chromatography relative to sugar-aldehyde $\mathbf{1}$.

Chloroiodomethyllithium gave the lowest stereoselectivities, producing $\mathbf{4 b}$ as the four possible isomers in 38:28:18:16 ratio (D/L-glycero 66/34; Table 2, entry 2). The use of the bigger dibromomethyl anion led to a significant increase in stereoselectivity generating $\mathbf{4 c}$ in $84 / 16$ D-/L-glycero ratio (Table 2 , entry 3). Finally, the best D-glycero selectivity was reached when the bulkier trimethylsilylchloromethyllithium anion was employed taking into account that a mixture of only two 4d isomers was obtained out of the four possible ones (Table 2, entry 4).

Owing to we have previously reported several 1,2-elimination processes on 1-halo-2-acetoxy compounds under several 
conditions, ${ }^{11-15}$ compounds $\mathbf{4}$ were transformed in the corresponding acetates $\mathbf{2}$ in excellent yields by treatment with $\mathrm{Ac}_{2} \mathrm{O}$ in pyridine and DMAP (Scheme 2).

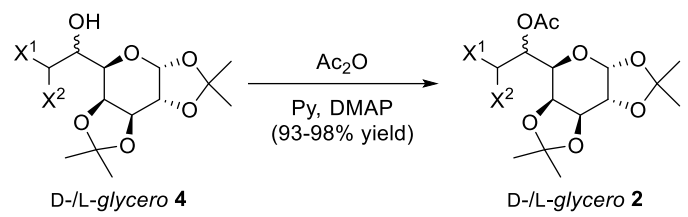

Scheme 2. Synthesis of D-L-glycero acetate derivatives 2 .

We next decided to explore the $\beta$-elimination process of halocarbinol acetates $\mathbf{2}$ for the preparation of the desired vinyl derivatives 3. For this purpose, we focused on samarium diiodide, a rather mild reagent widely employed to promote various $\beta$ elimination reactions with high or total stereoselectivity. ${ }^{21}$ Taking into account our previous results, halocarbinol acetates 2 (as a mixture of D-/L-glycero stereoisomers) were treated with 2.5 equiv. of $\mathrm{SmI}_{2}$ in THF at reflux (Table 3 ). Under these conditions, the desired $(Z)$-vinyl halides 3a-c were isolated in very high to excellent yields and selectivities (Table 3, entries 1-3). Similarly, the vinylsilane 3d was obtained from 2d in $97 \%$ yield although with moderate selectivity (Table 3 , entry 4 ).

Table 3. Synthesis of (Z)-vinyl halides 3a-c and silane 3d.
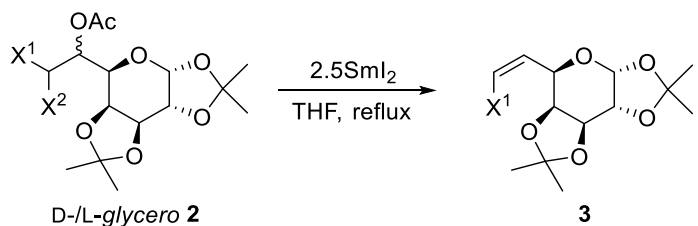

\begin{tabular}{cccccc}
\hline Entry & $\mathrm{X}^{1}$ & $\mathrm{X}^{2}$ & $\mathbf{3}$ & $Z / E^{\mathrm{a}}$ & Yield $(\%)^{\mathrm{b}}$ \\
\hline 1 & $\mathrm{I}$ & $\mathrm{I}$ & $\mathbf{3 a}$ & $95 / 5$ & 90 \\
2 & $\mathrm{Cl}$ & $\mathrm{I}$ & $\mathbf{3 b}$ & $96 / 4$ & 95 \\
3 & $\mathrm{Br}$ & $\mathrm{Br}$ & $\mathbf{3 c}$ & $94 / 6$ & 97 \\
4 & $\mathrm{SiMe}_{3}$ & $\mathrm{Cl}$ & $\mathbf{3 d}$ & $81 / 19$ & 97 \\
\hline
\end{tabular}

${ }^{\mathrm{a}} \mathrm{Z} / \mathrm{E}$ ratio was determined by ${ }^{1} \mathrm{H}$ NMR analysis on the crude reaction mixture. ${ }^{\mathrm{b}}$ Isolated yield of compounds $\mathbf{3}$ after column chromatography relative to starting materials $\mathbf{2}$.

The $(Z)$-relative configuration of the $\mathrm{C}=\mathrm{C}$ bonds in compounds 3 was assigned by analysis of ${ }^{1} \mathrm{H}$ NMR coupling constants between the olefinic protons. Moreover, spectroscopic data for compound (Z)-3c were compared to the previous values reported in the literature for the corresponding $(E)$-isomer. ${ }^{10}$
The synthesis of (Z)-vinyl halides 3a-c or silane $\mathbf{3 d}$ could be explained as follows: reaction of starting materials $\mathbf{2}$ with a first equivalent of samarium diiodide would generate a radical intermediate 5. Then a second equivalent of samarium diiodide would reduce the radical specie 5 to the anionic intermediate $\mathbf{6}$, which afforded the corresponding ( $Z$ )-vinyl compound $\mathbf{3}$ after 1,2elimination. The observed $(Z)$-stereochemistry of compounds $\mathbf{3}$ may be explained as a consequence of the ability of Sm(III) species to form chelates due to their high oxophilicity. ${ }^{22}$ Thus, chelation of $\mathrm{Sm}(\mathrm{III})$ center with the oxygen atom of the acetyl group leads to a six-membered ring 6 which triggered the 1,2-elimination process by increasing the ability of the acetoxy as a leaving group (as depicted in Scheme 3).

This reaction occurred in a stereoselective fashion but not in a stereospecific manner since the diastereoisomeric ratio rise from compounds $\mathbf{2}$ to $\mathbf{3}$. This may happen as a consequence of a loss of the chiral information contained on the $\mathrm{CHX}^{1} \mathrm{X}^{2}$ center after the addition of a first equivalent of samarium diiodide and further generation of radical specie 5. In this sense, the six-membered ring may be formed as the two chairs (see intermediates I and II in Scheme 3) which structure depends on the spatial disposition of the acetate group.

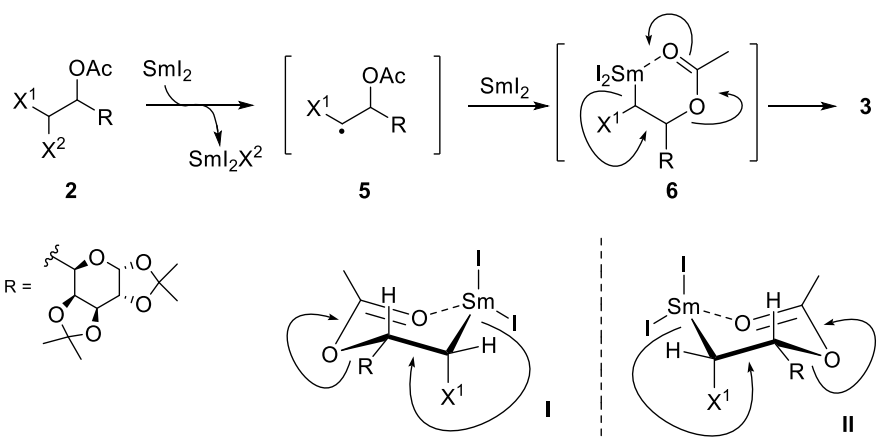

Scheme 3. Proposed mechanism for the synthesis of $(Z)$-vinyl compounds 3 .

Chelation-control model depicted in Scheme 3 would explain the $(Z)$-selectivity observed in this reaction. Chair-like structure III is assumed, in which the $\mathrm{R}$ (sugar moiety), and $\mathrm{X}^{1}(\mathrm{Cl}, \mathrm{Br}, \mathrm{I}$, $\mathrm{SiMe}_{3}$ ) adopt an equatorial and axial position, respectively. This is due to both, on the one hand, the absence of 1,3-diaxial interactions and, on the other hand, as a consequence that dipoles $\mathrm{Sm}-\mathrm{I}$ and $\mathrm{C}-\mathrm{X}^{1}$ are opposite. Elimination process, as shown in intermediates I and II, would afford ( $Z$ )-vinyl compounds $\mathbf{3}$.

As it is shown in Table 3, the lower $Z / E$ ratio observed in compound 3d, when compared with 3a-c, can be explain due to the higher steric requirements of the TMS group. This fact has been already observed in other 1,2-elimination protocols in which 1-halo-2-acetoxyalkylsilanes are involved. ${ }^{12}$ 
Tetrahedron

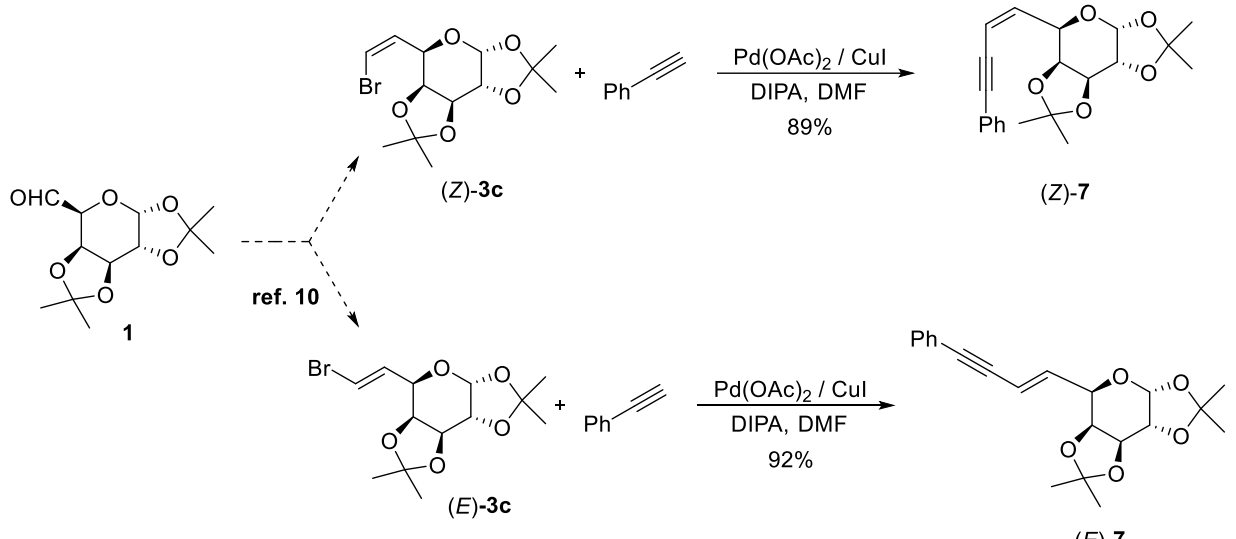

$(E)-7$

Scheme 4. Synthesis of sugar-derived enyne derivatives $(E)$ - and (Z)-7.

In order to evaluate the usefulness of the aforementioned sugarvinyls in cross-coupling reactions, bromovinyl $\mathbf{3 c}$ was selected to examine a Sonogashira cross-coupling reaction. Thus, sugar bromoalkene 3c was subjected to the standard protocol with ethynyl benzene using $5 \mathrm{~mol} \% \mathrm{Pd}(\mathrm{OAc})_{2}$ and $5 \mathrm{~mol} \% \mathrm{CuI}$ in the presence of 0.2 equiv. of $\mathrm{PPh}_{3}$ and diisopropylamine as base. Under these conditions, enyne ( $Z$ )-7 was obtained (Scheme 4). This enyne is isomeric to the previously we reported from the corresponding $(E)$-bromoalkene $(E)$-3c. ${ }^{10}$ Taking into account that the $(E)$-bromovinylsugars $(E)-\mathbf{3}$ are easily available from sugar dibromoalkenes on indium promoted debromination on ionic liquid under ohmic heating, both procedures are complementary and give access to both isomers of sugar enyne derivatives 7 .

\section{Conclusion}

In conclusion, we have described a novel protocol directed towards the synthesis of carbohydrate-derived $(Z)$-vinyl halides and silanes. This process took place with a good control of the stereoselectivity and high yields. Besides, this procedure complements our described methodology for the preparation of sugar-derived $(E)$-vinyl halides. A mechanism that explains both, the formation of compounds $\mathbf{3}$ and its selectivity is proposed. Sonogashira coupling of both $(E)$ - and (Z)-vinyl bromides generated the corresponding $(E)$ - and $(Z)$-enynes with total stereoselectivity and good yields. Other synthetic applications of both $(E)$ - or $(Z)$-vinyl halides are currently under investigation in our laboratory.

\section{Experimental section}

Reactions that required an inert atmosphere were conducted under dry nitrogen, and the glassware was oven dried $\left(120^{\circ} \mathrm{C}\right)$. THF was distilled using sodium-benzophenone as desiccant immediately prior to use. All reagents were commercially available and were used without further purification. Silica gel for column chromatography purifications was purchased from Merck (230$400 \mathrm{mesh}$ ), and compounds were visualized on analytical thin layer chromatograms (TLC) by UV light $(254 \mathrm{~nm}) .{ }^{1} \mathrm{H}$ NMR spectra were recorded in a Brüker $300 \mathrm{MHz}$ spectrometer. Chemical shifts are given in ppm relative to tetramethylsilane (TMS), which is used as an internal standard, and coupling constants $J$ are reported in Hz. The diastereoisomeric ratios were obtained from ${ }^{1} \mathrm{H}$ NMR analysis. GC-MS and HRMS were measured at $70 \mathrm{eV}$. Only the most important molecular ions and/or base peaks in MS are given.

4.1. General procedure for the synthesis of sugar-derived $\alpha$ halomethylcarbinols 4: To a solution of the galactose derived aldehyde 1 (10 mmol) and the corresponding dihalomethane or (chloromethyl)trimethylsilane $(20 \mathrm{mmol})$ in THF $(20 \mathrm{~mL})$ was added dropwise at $-78{ }^{\circ} \mathrm{C}$, lithium diisopropylamide [prepared from $n$-BuLi (12.5 mL, 1.6 M solution in hexanes, $20 \mathrm{mmol}$ ), and diisopropylamine $(2.82 \mathrm{~mL}, 20 \mathrm{mmol})$ in $\mathrm{THF}(20 \mathrm{~mL})$ at $\left.0{ }^{\circ} \mathrm{C}\right]$. After stirring for $2 \mathrm{~h}$ the reaction mixture was quenched by addition of a saturated aqueous $\mathrm{NH}_{4} \mathrm{Cl}$ solution $(10 \mathrm{~mL})$. Standard workup provided crude $\alpha$-halomethylcarbinols 4 which were purified by column chromatography (silica gel, hexane/EtOAc as eluent).

4.1.a. 7-Deoxy-7,7-diiodo-1,2:3,4-di-O-isopropylidene-D,Lglycero- $\beta$-galacto-heptopyranose 4a: Yellow oil, $[\alpha]_{\mathrm{D}}^{22}-43.7^{\circ}$ (c $1.0, \mathrm{CHCl}_{3}$ ), yield $86 \%$. Data for major isomer D-glycero: ${ }^{1} \mathrm{H} \mathrm{NMR}$ $\left(300 \mathrm{MHz}, \mathrm{CDCl}_{3}\right): \delta 5.56(\mathrm{~d}, J 5.1 \mathrm{~Hz}, 1 \mathrm{H}, \mathrm{H}-1), 5.42(\mathrm{~d}, J 3.8$ Hz, $1 \mathrm{H}, \mathrm{H}-7$ ), 4.64 (dd, J 7.9, $2.5 \mathrm{~Hz}, 1 \mathrm{H}, \mathrm{H}-3$ ), 4.35 (dd, J 5.1, $2.5 \mathrm{~Hz}, 1 \mathrm{H}, \mathrm{H}-2), 4.24$ (dd, $J$ 7.9, $2.0 \mathrm{~Hz}, 1 \mathrm{H}, \mathrm{H}-4), 3.91$ (dd, $J$ 5.8, $2.0 \mathrm{~Hz}, 1 \mathrm{H}, \mathrm{H}-5), 3.91$ (dd, J 5.8, $3.8 \mathrm{~Hz}, 1 \mathrm{H}, \mathrm{H}-6), 1.59$ (s, $3 \mathrm{H}), 1.44$ (s, $3 \mathrm{H}), 1.34$ (s, $3 \mathrm{H}), 1.33$ (s, $3 \mathrm{H}) .{ }^{13} \mathrm{C} \mathrm{NMR}(75 \mathrm{MHz}$, $\left.\mathrm{CDCl}_{3}\right): \delta 110.0,109.2,96.4,75.7,71.0,70.8,70.3,69.4,26.1$, 25.8, 25.0, 24.3, -24.1. MS (ESI $\left.{ }^{+}-\mathrm{TOF}, \mathrm{m} / z, \%\right): 549\left([\mathrm{M}+\mathrm{Na}]^{+}\right.$, 100). HRMS (ESI ${ }^{+}$): calcd. for $\mathrm{C}_{13} \mathrm{H}_{20} \mathrm{I}_{2} \mathrm{O}_{6} \mathrm{Na}[\mathrm{M}+\mathrm{Na}]^{+} 548.9241$, found $548.9215 ; R_{f}=0.33$ (hexane/EtOAc 3:1).

4.1.b. 7-Chloro-7-deoxy-7-iodo-1,2:3,4-di-O-isopropylidene-D, Lglycero- $\beta$-D-galacto-heptopyranose $4 \boldsymbol{b}$ : Yellow oil, $[\alpha]_{\mathrm{D}}{ }^{22}-24.2^{\circ}$ (c $1.0, \mathrm{CHCl}_{3}$ ), yield $64 \%$. Data for major isomer D-glycero: ${ }^{1} \mathrm{H}$ NMR (300 MHz, $\left.\mathrm{CDCl}_{3}\right): \delta 6.16(\mathrm{~d}, J 1.3 \mathrm{~Hz}, 1 \mathrm{H}, \mathrm{H}-7), 5.49(\mathrm{~d}$, $J 4.9 \mathrm{~Hz}, 1 \mathrm{H}, \mathrm{H}-1$ ), 4.67 (dd, $J$ 8.0, $2.5 \mathrm{~Hz}, 1 \mathrm{H}, \mathrm{H}-3$ ), 4.50 (dd, $J$ 8.0, $1.9 \mathrm{~Hz}, 1 \mathrm{H}, \mathrm{H}-4), 4.34$ (dd, J 4.9, $2.5 \mathrm{~Hz}, 1 \mathrm{H}, \mathrm{H}-2), 4.11$ (d, $J 9.0 \mathrm{~Hz}, 1 \mathrm{H}, \mathrm{H}-6), 3.79$ (dd, $J 9.0,1.9 \mathrm{~Hz}, 1 \mathrm{H}, \mathrm{H}-5$ ), 2.66 (br s, $1 \mathrm{H}, \mathrm{OH}), 1.57$ (s, $3 \mathrm{H}), 1.47$ (s, $3 \mathrm{H}), 1.39$ (s, $3 \mathrm{H}), 1.34$ (s, $3 \mathrm{H})$. ${ }^{13} \mathrm{C} \mathrm{NMR}\left(75 \mathrm{MHz}, \mathrm{CDCl}_{3}\right): \delta 109.3,109.0,96.0,74.5,70.5,70.2$, $67.9,51.1,25.9,24.9,24.3$. MS (ESI+-TOF, $\mathrm{m} / \mathrm{z}, \%): 459$ $\left([\mathrm{M}+\mathrm{Na}]^{+},{ }^{37} \mathrm{Cl}, 17\right), 457\left([\mathrm{M}+\mathrm{Na}]^{+},{ }^{35} \mathrm{Cl}, 100\right)$. HRMS $\left(\mathrm{ESI}^{+}\right)$: calcd. for $\mathrm{C}_{13} \mathrm{H}_{20} \mathrm{ClIO}_{6} \mathrm{Na}[\mathrm{M}+\mathrm{Na}]^{+} 456.9885$, found 456.9883; $R_{f}$ $=0.35$ (hexane/EtOAc 3:1).

4.1.c. 7,7-Dibromo-7-deoxy-1,2:3,4-di-O-isopropylidene-D, Lglycero- $\beta$-D-galacto-heptopyranose $4 c$ : Yellow oil, $[\alpha]_{\mathrm{D}}^{22}-45.7^{\circ}$ (c 1.0, $\mathrm{CHCl}_{3}$ ), yield 79\%. Data for major isomer D-glycero: ${ }^{1} \mathrm{H}$ NMR (300 MHz, $\left.\mathrm{CDCl}_{3}\right): \delta 6.14(\mathrm{~d}, J 1.3 \mathrm{~Hz}, 1 \mathrm{H}, \mathrm{H}-7), 5.48$ (d, $J 4.9 \mathrm{~Hz}, 1 \mathrm{H}, \mathrm{H}-1), 4.65$ (dd, $J$ 8.0, $2.5 \mathrm{~Hz}, 1 \mathrm{H}, \mathrm{H}-3), 4.49$ (dd, $J$ 8.0, $1.8 \mathrm{~Hz}, 1 \mathrm{H}, \mathrm{H}-4), 4.32$ (dd, J 4.9, $2.5 \mathrm{~Hz}, 1 \mathrm{H}, \mathrm{H}-2$ ), 4.27 (dd, $J$ 9.1, $1.8 \mathrm{~Hz}, 1 \mathrm{H}, \mathrm{H}-5), 4.09$ (d, J 9.1 Hz, $1 \mathrm{H}, \mathrm{H}-6), 1.55$ (s, $3 \mathrm{H})$, $1.45(\mathrm{~s}, 3 \mathrm{H}), 1.37(\mathrm{~s}, 3 \mathrm{H}), 1.32(\mathrm{~s}, 3 \mathrm{H}) .{ }^{13} \mathrm{C}$ NMR $(75 \mathrm{MHz}$, $\left.\mathrm{CDCl}_{3}\right): \delta 109.3,109.0,95.5,74.5,70.4,70.2,68.6,50.8,25.8$, 
24.8, 24.3. MS (ESI+ $-\mathrm{TOF}, m / z, \%): 457\left([\mathrm{M}+\mathrm{Na}]^{+},{ }^{81} \mathrm{Br}_{2}, 30\right), 455$ $\left([\mathrm{M}+\mathrm{Na}]^{+},{ }^{81} \mathrm{Br}^{79} \mathrm{Br}, 100\right), 453\left([\mathrm{M}+\mathrm{Na}]^{+},{ }^{79} \mathrm{Br}_{2}, 39\right)$. HRMS $\left(\mathrm{ESI}^{+}\right)$: calcd. for $\mathrm{C}_{13} \mathrm{H}_{20} \mathrm{Br}_{2} \mathrm{O}_{6} \mathrm{Na}[\mathrm{M}+\mathrm{Na}]^{+}$452.9519, found 452.9507; $R_{f}=0.35$ (hexane/EtOAc 3:1).

\section{1.d. 7-Chloro-7-deoxy-1,2:3,4-di-O-isopropylidene-7-} trimethylsilyl-D,L-glycero- $\beta$-D-galacto-heptopyranose $4 d$ : Yellow oil, $[\alpha]_{\mathrm{D}}^{22}-22.5^{\circ}\left(\mathrm{c} 1.0, \mathrm{CHCl}_{3}\right)$, yield $70 \%$. Data for major isomer D-glycero: ${ }^{1} \mathrm{H} \mathrm{NMR}\left(300 \mathrm{MHz}, \mathrm{CDCl}_{3}\right): \delta 5.51(\mathrm{~d}, J 4.9 \mathrm{~Hz}, 1 \mathrm{H}$, H-1), 4.65 (dd, $J 8.0,2.5 \mathrm{~Hz}, 1 \mathrm{H}, \mathrm{H}-3$ ), 4.46 (dd, $J 8.0,1.9 \mathrm{~Hz}, 1$ $\mathrm{H}, \mathrm{H}-4), 4.32$ (dd, J 4.9, $2.5 \mathrm{~Hz}, 1 \mathrm{H}, \mathrm{H}-2), 4.04-4.01$ (m, $1 \mathrm{H}, \mathrm{H}-$ 6), 3.94 (dd, $J 8.9,1.9 \mathrm{~Hz}, 1 \mathrm{H}, \mathrm{H}-5), 3.87$ (d, $J 1.1 \mathrm{~Hz}, 1 \mathrm{H}, \mathrm{H}-7$ ), 1.58 (s, $3 \mathrm{H}), 1.45$ (s, $3 \mathrm{H}), 1.37$ (s, $3 \mathrm{H}), 1.33$ (s, $3 \mathrm{H}), 0.17$ (s, 9 H). ${ }^{13} \mathrm{C}$ NMR $\left(75 \mathrm{MHz}, \mathrm{CDCl}_{3}\right): \delta 109.2,108.9,96.2,70.7,70.6$, 69.8, 67.1, 53.6, 25.9, 24.9, 24.3, -2.8. MS (ESI+-TOF, $m / z, \%)$ : $405\left([\mathrm{M}+\mathrm{Na}]^{+},{ }^{37} \mathrm{Cl}, 47\right), 403\left([\mathrm{M}+\mathrm{Na}]+{ }^{+}{ }^{35} \mathrm{Cl}, 100\right)$. HRMS $\left(\mathrm{ESI}^{+}\right)$: calcd. for $\mathrm{C}_{16} \mathrm{H}_{29} \mathrm{ClO}_{6} \mathrm{SiNa}[\mathrm{M}+\mathrm{Na}]^{+} 403.1314$, found 403.1303; $R_{f}$ $=0.36($ hexane $/$ EtOAc 3:1).

4.2. General procedure for the synthesis of halocarbinol acetates 2: The corresponding halocarbinol $4(1.0 \mathrm{mmol})$ was taken up in pyridine $(8 \mathrm{~mL})$ and acetic anhydride $(8 \mathrm{~mL})$. DMAP $(6 \mathrm{mg})$ was added and after stirring at room temperature for $6 \mathrm{~h}$, the reaction mixture was poured over ice-cooled water $(20 \mathrm{~mL})$ and extracted with $\mathrm{CH}_{2} \mathrm{Cl}_{2}(3 \times 30 \mathrm{~mL})$. The combined organic layers were washed with a saturated aqueous $\mathrm{NaHCO}_{3}$ solution (40 $\mathrm{mL})$, a saturated aqueous $\mathrm{CuSO}_{4}$ solution $(40 \mathrm{~mL})$, brine $(40 \mathrm{~mL})$, and dried over anhydrous $\mathrm{Na}_{2} \mathrm{SO}_{4}$. After filtration, the solvents were removed under reduced pressure. This allowed the access to halocarbinol acetates 2 in almost quantitative manner (93-98\% yield).

4.2.a. 6-O-Acetyl-7-deoxy-7,7-diiodo-1,2:3,4-di-Oisopropylidene-D,L-glycero- $\beta$-D-galacto-heptopyranose $2 \boldsymbol{2 a}$ : Yellow oil, yield 93\%. Data for major isomer D-glycero: ${ }^{1} \mathrm{H}$ NMR $\left(300 \mathrm{MHz}, \mathrm{CDCl}_{3}\right): \delta 5.50(\mathrm{~d}, J 2.8 \mathrm{~Hz}, 1 \mathrm{H}, \mathrm{H}-1), 5.47$ (d, $J 5.1$ $\mathrm{Hz}, 1 \mathrm{H}, \mathrm{H}-7), 5.07$ (dd, $J 7.4,2.8 \mathrm{~Hz}, 1 \mathrm{H}, \mathrm{H}-5), 4.61$ (dd, $J 7.8$, $2.8 \mathrm{~Hz}, 1 \mathrm{H}, \mathrm{H}-2), 4.30$ (dd, J 5.1, $2.8 \mathrm{~Hz}, 1 \mathrm{H}, \mathrm{H}-6), 4.18$ (dd, $J$ 7.8, $2.1 \mathrm{~Hz}, 1 \mathrm{H}, \mathrm{H}-3), 3.88$ (dd, J 7.4, $2.1 \mathrm{~Hz}, 1 \mathrm{H}, \mathrm{H}-4), 2.20$ (s, $3 \mathrm{H}), 1.55(\mathrm{~s}, 3 \mathrm{H}), 1.44(\mathrm{~s}, 3 \mathrm{H}), 1.32(\mathrm{~s}, 3 \mathrm{H}), 1.30(\mathrm{~s}, 3 \mathrm{H}),{ }^{13} \mathrm{C}$ NMR $\left(75 \mathrm{MHz}, \mathrm{CDCl}_{3}\right): \delta 169.7,110.2,108.9,96.3,75.2,70.8$, 70.4, 70.1, 25.9, 25.0, 24.6, 21.0, -31.2. MS (ESI+-TOF, $m / z, \%)$ : $590\left([\mathrm{M}+\mathrm{Na}]^{+}, 100\right)$. HRMS $\left(\mathrm{ESI}^{+}\right)$: calcd. for $\mathrm{C}_{15} \mathrm{H}_{22} \mathrm{I}_{2} \mathrm{O}_{7} \mathrm{Na}$ $[\mathrm{M}+\mathrm{Na}]^{+} 590.9356$, found 590.9353; $R_{f}=0.43$ (hexane/EtOAc $3: 1)$.

4.2.b. 6-O-Acetyl-7-chloro-7-deoxy-7-iodo-1,2:3,4-di-Oisopropylidene-D,L-glycero- $\beta$-D-galacto-heptopyranose $2 \boldsymbol{b}$ : Yellow oil, yield 96\%. Data for major isomer D-glycero: ${ }^{1} \mathrm{H}$ NMR $\left(300 \mathrm{MHz}, \mathrm{CDCl}_{3}\right): \delta 6.14(\mathrm{~d}, J 1.4 \mathrm{~Hz}, 1 \mathrm{H}, \mathrm{H}-7), 5.60-5.56(\mathrm{~m}$, $1 \mathrm{H}, \mathrm{H}-6), 5.42$ (d, J 4.8 Hz, $1 \mathrm{H}, \mathrm{H}-1), 4.574 .52$ (m, $1 \mathrm{H}, \mathrm{H}-3)$, 4.27-4.25 (m, $1 \mathrm{H}, \mathrm{H}-2), 4.08-4.01$ (m, $1 \mathrm{H}, \mathrm{H}-4), 3.69-3.66$ (m, 1 H, H-5), 2.14 (s, $3 \mathrm{H}), 1.47$ (s, $3 \mathrm{H}), 1.37$ (s, $3 \mathrm{H}), 1.27$ (s, $3 \mathrm{H})$, $1.26(\mathrm{~s}, 3 \mathrm{H}) .{ }^{13} \mathrm{C} \mathrm{NMR}\left(75 \mathrm{MHz}, \mathrm{CDCl}_{3}\right): \delta 168.1,109.5,108.9$, 95.9, 73.2, 69.9, 67.6, 32.2, 25.7, 24.4, 24.2, 20.7. HRMS (ESI+): calcd. for $\mathrm{C}_{15} \mathrm{H}_{22} \mathrm{ClIO}_{7} \mathrm{Na}[\mathrm{M}+\mathrm{Na}]^{+} 499.9885$, found $499.9883 ; R_{f}$ $=0.48$ (hexane/EtOAc 3:1).

4.2.c. 6-O-Acetyl-7,7-dibromo-7-deoxy-1,2:3,4-di-Oisopropylidene-D,L-glycero- $\beta$-D-galacto-heptopyranose $2 c$ : Yellow oil, yield 98\%. Data for major isomer D-glycero: ${ }^{1} \mathrm{H}$ NMR $\left(300 \mathrm{MHz}, \mathrm{CDCl}_{3}\right): \delta 6.07$ (d, $\left.J 1.4 \mathrm{~Hz}, 1 \mathrm{H}, \mathrm{H}-7\right), 5.54$ (dd, $J 9.2$, $1.4 \mathrm{~Hz}, 1 \mathrm{H}, \mathrm{H}-6), 5.49$ (d, J 4.9 Hz, $1 \mathrm{H}, \mathrm{H}-1$ ), 4.61 (dd, J 7.9, 2.5 $\mathrm{Hz}, 1 \mathrm{H}, \mathrm{H}-3$ ), 4.33 (dd, J 4.9, $2.5 \mathrm{~Hz}, 1 \mathrm{H}, \mathrm{H}-2$ ), 4.17 (dd, J 7.8, $1.7 \mathrm{~Hz}, 1 \mathrm{H}, \mathrm{H}-4), 3.94$ (dd, J 9.2, $1.6 \mathrm{~Hz}, 1 \mathrm{H}, \mathrm{H}-5), 2.20$ (s, $3 \mathrm{H}$ ), $1.57(\mathrm{~s}, 3 \mathrm{H}), 1.44(\mathrm{~s}, 3 \mathrm{H}), 1.33(\mathrm{~s}, 3 \mathrm{H}), 1.31(\mathrm{~s}, 3 \mathrm{H}) .{ }^{13} \mathrm{C} \mathrm{NMR}$ $\left(75 \mathrm{MHz}, \mathrm{CDCl}_{3}\right): \delta 168.2,109.5,109.0,95.9,73.1,70.4,69.7$, 68.1, 44.6, 25.8, 24.8, 24.3, 20.6. MS (ESI ${ }^{+}$-TOF, $m / z, \%$ ): 499 $\left([\mathrm{M}+\mathrm{Na}]^{+},{ }^{81} \mathrm{Br}_{2}, \quad 55\right), 497 \quad\left([\mathrm{M}+\mathrm{Na}]^{+},{ }^{81} \mathrm{Br}^{79} \mathrm{Br}, \quad 100\right), 495$ $\left([\mathrm{M}+\mathrm{Na}]^{+},{ }^{79} \mathrm{Br}_{2}, 55\right)$. HRMS (ESI ${ }^{+}$): calcd. for $\mathrm{C}_{15} \mathrm{H}_{22} \mathrm{Br}_{2} \mathrm{O}_{7} \mathrm{Na}$ $[\mathrm{M}+\mathrm{Na}]^{+} 494.9630$, found 494.9641; $R_{f}=0.50$ (hexane/EtOAc $3: 1)$.

4.2.d. 6-O-Acetyl-7-chloro-7-deoxy-1,2:3,4-di-O-isopropylidene7-trimethylsilyl-D,L-glycero- $\beta$-D-galacto-heptopyranose $2 d$ : Yellow oil, yield 93\%. Data for major isomer D-glycero: ${ }^{1} \mathrm{H}$ NMR $\left(300 \mathrm{MHz}, \mathrm{CDCl}_{3}\right): \delta 5.51(\mathrm{~d}, J 5.0 \mathrm{~Hz}, 1 \mathrm{H}, \mathrm{H}-1), 5.36(\mathrm{dd}, J$ 9.1, $1.4 \mathrm{~Hz}, 1 \mathrm{H}, \mathrm{H}-6), 4.46$ (dd, $J 8.0,2.0 \mathrm{~Hz}, 1 \mathrm{H}, \mathrm{H}-3$ ), 4.32 (dd, $J$ 5.0, 2.0 Hz, $1 \mathrm{H}, \mathrm{H}-2), 4.25-4.12$ (m, $1 \mathrm{H}, \mathrm{H}-4, \mathrm{H}-5), 3.87$ (d, J 1.4 $\mathrm{Hz}, 1 \mathrm{H}, \mathrm{H}-7), 2.10$ (s, $3 \mathrm{H}), 1.52$ (s, $3 \mathrm{H}), 1.48$ (s, $3 \mathrm{H}), 1.33$ (s, 3 $\mathrm{H}), 1.27(\mathrm{~s}, 3 \mathrm{H}), 0.38(\mathrm{~s}, 9 \mathrm{H}),{ }^{13} \mathrm{C}$ NMR $\left(75 \mathrm{MHz}, \mathrm{CDCl}_{3}\right): \delta$ 168.8, 109.4, 109.0, 96.3, 70.8, 70.7, 70.3, 70.2, 66.0, 50.8, 25.9, 25.8, 24.9, 24.4, 21.0, -3.1. HRMS (ESI+): calcd. for $\mathrm{C}_{18} \mathrm{H}_{31} \mathrm{ClO}_{7} \mathrm{SiNa}[\mathrm{M}+\mathrm{Na}]+446.1314$, found $446.1311 ; R_{f}=0.46$ (hexane/EtOAc 3:1).

4.3. General procedure for the synthesis of (Z)-vinyl compounds 3: A solution of the resulting intermediate acetates 2 in THF $(20 \mathrm{~mL})$ was added to $0.1 \mathrm{M}$ solution of samarium diiodide in THF (2.5 mmol). After stirring the reaction mixture at reflux for $18 \mathrm{~h}$, an aqueous $\mathrm{HCl} 0.1 \mathrm{M}$ solution $(20 \mathrm{~mL})$ was added and the aqueous phase was extracted with $\mathrm{Et}_{2} \mathrm{O}(3 \times 20 \mathrm{~mL})$. The combined organic layers were then dried over anhydrous $\mathrm{Na}_{2} \mathrm{SO}_{4}$ and the solvent was removed under reduced pressure. The residue was purified by column chromatography eluting with mixtures of hexane/ethyl acetate to afford (Z)-vinyl compounds 3 (90-97\% yield).

4.3.a. (Z)-6,7-Dideoxy-1,2:3,4-di-O-isopropylidene-7-iodo- $\beta$ - $D$ galacto-hept-6-enopyranose 3a: Yellow oil, $[\alpha]_{\mathrm{D}}{ }^{22}-75.4^{\circ}$ (c 1.0, $\left.\mathrm{CHCl}_{3}\right)$, yield $90 \% .{ }^{1} \mathrm{H} \mathrm{NMR}\left(300 \mathrm{MHz}, \mathrm{CDCl}_{3}\right): \delta 6.48-6.42(\mathrm{~m}$, $1 \mathrm{H}, \mathrm{H}-6, \mathrm{H}-7), 5.55$ (d, J 5.0 Hz, $1 \mathrm{H}, \mathrm{H}-1), 4.66$ (dd, J 7.8, 2.5 $\mathrm{Hz}, 1 \mathrm{H}, \mathrm{H}-3$ ), 4.60 (dd, $J$ 6.0, $2.0 \mathrm{~Hz}, 1 \mathrm{H}, \mathrm{H}-5$ ), 4.34 (dd, J 5.0, $2.5 \mathrm{~Hz}, 1 \mathrm{H}, \mathrm{H}-2), 4.32$ (dd, J 7.9, $2.0 \mathrm{~Hz}, 1 \mathrm{H}, \mathrm{H}-4), 1.67$ (s, $3 \mathrm{H}$ ), $1.47(\mathrm{~s}, 3 \mathrm{H}), 1.35(\mathrm{~s}, 3 \mathrm{H}), 1.34(\mathrm{~s}, 3 \mathrm{H}) .{ }^{13} \mathrm{C}$ NMR $(75 \mathrm{MHz}$, $\left.\mathrm{CDCl}_{3}\right): \delta 137.8,109.4,108.9,96.3,83.3,72.1,71.4,70.6,70.1$, 26.2, 25.8, 25.0, 24.3. MS (ESI $\left.{ }^{+}-\mathrm{TOF}, \mathrm{m} / z, \%\right): 357\left([\mathrm{M}+\mathrm{Na}]^{+}, 4\right)$, 241 (100); HRMS (ESI ${ }^{+}$): calcd. for $\mathrm{C}_{21} \mathrm{H}_{25} \mathrm{O}_{5}[\mathrm{M}+\mathrm{H}]^{+} 357.1696$, found 357.1707; $R_{f}=0.60$ (hexane/EtOAc 3:1).

4.3.b. (Z)-7-Chloro-6,7-dideoxy-1,2:3,4-di-O-isopropylidene- $\beta$ D-galacto-hept-6-enopyranose $3 \boldsymbol{b}$ : Yellow oil, $[\alpha]_{\mathrm{D}}^{22}-4.5^{\circ}$ (c 0.2 , $\mathrm{CHCl}_{3}$ ), yield $97 \% .{ }^{1} \mathrm{H}$ NMR $\left(300 \mathrm{MHz}, \mathrm{CDCl}_{3}\right): \delta 6.19(\mathrm{dd}, J 7.4$, $1.1 \mathrm{~Hz}, 1 \mathrm{H}, \mathrm{H}-7), 5.96$ (t, J 7.4 Hz, $1 \mathrm{H}, \mathrm{H}-6), 5.53$ (d, J $5.0 \mathrm{~Hz}, 1$ H, H-1), 4.86 (d, J 7.9 Hz, $1 \mathrm{H}, \mathrm{H}-3), 4.63$ (dd, J 7.9, $2.5 \mathrm{~Hz}, 1 \mathrm{H}$, H-5), 4.32 (dd, J 5.0, $2.5 \mathrm{~Hz}, 1 \mathrm{H}, \mathrm{H}-2), 4.27$ (dd, J 7.9, $2.0 \mathrm{~Hz}, 1$ H, H-4), 1.59 (s, 3 H), 1.46 (s, $3 \mathrm{H}), 1.34$ (s, $3 \mathrm{H}), 1.33$ (s, $3 \mathrm{H})$. ${ }^{13} \mathrm{C}$ NMR (75 MHz, $\left.\mathrm{CDCl}_{3}\right): \delta 128.2,120.2,109.3,108.8,96.3$, 72.3, 70.7, 70.2, 64.6, 26.0, 25.9, 24.9, 24.2. MS (ESI+ - TOF, $\mathrm{m} / \mathrm{z}$, $\%): 313\left([\mathrm{M}+\mathrm{Na}]^{+}, 100\right)$. HRMS $\left(\mathrm{ESI}^{+}\right)$: calcd. for $\mathrm{C}_{21} \mathrm{H}_{25} \mathrm{O}_{5}$ $[\mathrm{M}+\mathrm{Na}]^{+} 313.0819$, found 313.0818. $R_{f}=0.58$ (hexane/EtOAc $3: 1)$.

4.3.c. (Z)-7-Bromo-6,7-dideoxy-1,2:3,4-di-O-isopropylidene- $\beta$ - $D$ galacto-hept-6-enopyranose $3 c$ : Yellow oil, $[\alpha]_{\mathrm{D}}^{22}-69.4^{\circ}$ (c 0.2 , $\mathrm{CHCl}_{3}$ ), yield $95 \% .{ }^{1} \mathrm{H} \mathrm{NMR}\left(300 \mathrm{MHz}, \mathrm{CDCl}_{3}\right): \delta 6.63(\mathrm{~d}, J=8.1$ $\mathrm{Hz}, 1 \mathrm{H}, \mathrm{H}-7), 6.48-6.27$ (m, $1 \mathrm{H}, \mathrm{H}-6), 5.52$ (d, $J=5.0 \mathrm{~Hz}, 1 \mathrm{H}$, $\mathrm{H}-1), 4.77$ (dd, $J=6.8,1.8 \mathrm{~Hz}, 1 \mathrm{H}, \mathrm{H}-2), 4.63$ (dd, $J=5.1,1.9$ Hz, 1 H, H-5), 4.33-4.27 (m, 2 H, H-3, H-4), 1.60 (s, 3 H), 1.45 (s, $3 \mathrm{H}), 1.33$ (s, $3 \mathrm{H}), 1.32(\mathrm{~s}, 3 \mathrm{H}) ;{ }^{13} \mathrm{C}$ NMR $\left(75 \mathrm{MHz}, \mathrm{CDCl}_{3}\right): \delta$ 131.5, 109.4, 109.3, 108.8, 96.2, 72.1, 70.6, 70.1, 67.1, 26.0, 25.8, 24.9, 24.2. MS (ESI - TOF, $m / z, \%): 359\left([\mathrm{M}+\mathrm{Na}]^{+},{ }^{81} \mathrm{Br}, 96\right), 357$ 
$\left([\mathrm{M}+\mathrm{Na}]^{+},{ }^{79} \mathrm{Br}, 100\right)$. HRMS $\left(\mathrm{ESI}^{+}\right)$calc. for $\mathrm{C}_{13} \mathrm{H}_{19} \mathrm{BrO}_{5} \mathrm{Na}$ $[\mathrm{M}+\mathrm{Na}]^{+} 357.0308$, found 357.0288; $R_{f}=0.28$ (hexane/EtOAc 9:1).

\section{3.d. (Z)-6,7-Dideoxy-1,2:3,4-di-O-isopropylidene-7-} trimethylsilyl- $\beta$-D-galacto-hept-6-enopyranose 3d: Yellow oil, $[\alpha]_{\mathrm{D}}^{22}-4.5^{\circ}$ (c $0.2, \mathrm{CHCl}_{3}$ ), yield 97\%. ${ }^{1} \mathrm{H} \mathrm{NMR}(300 \mathrm{MHz}$, $\mathrm{CDCl}_{3}$ ): $\delta 6.36(\mathrm{dd}, J 14.7,7.7 \mathrm{~Hz}, 1 \mathrm{H}, \mathrm{H}-6), 6.36$ (dd, $J 14.7,1.1$ $\mathrm{Hz}, 1 \mathrm{H}, \mathrm{H}-7), 5.58$ (d, J 5.2 Hz, $1 \mathrm{H}, \mathrm{H}-1), 4.61$ (dd, J 7.7, $2.3 \mathrm{~Hz}$, $1 \mathrm{H}, \mathrm{H}-5), 4.43$ (d, J 7.1 Hz, $1 \mathrm{H}, \mathrm{H}-4), 4.31$ (dd, J 5.2, $2.3 \mathrm{~Hz}, 1$ H, H-2), 4.18 (dd, J 7.7, 2.3 Hz, 1 H, H-3), 1.55 (s, $3 \mathrm{H}$ ), 1.48 (s, $3 \mathrm{H}), 1.34$ (s, $6 \mathrm{H}), 0.15$ (s, $3 \mathrm{H}) \cdot{ }^{13} \mathrm{C} \mathrm{NMR}\left(75 \mathrm{MHz}, \mathrm{CDCl}_{3}\right): \delta$ 143.3, 132.6, 109.1, 108.2, 96.2, 73.8, 70.9, 70.0, 68.1, 26.0, 25.9, 24.7, 24.2, 0.3. MS (ESI+ ${ }^{+}$TOF, $\left.m / z, \%\right): 351\left([\mathrm{M}+\mathrm{Na}]^{+}, 100\right)$. HRMS $\left(\mathrm{ESI}^{+}\right)$: calcd. for $\mathrm{C}_{16} \mathrm{H}_{28} \mathrm{O}_{5} \mathrm{SiNa}[\mathrm{M}+\mathrm{Na}]^{+} 351.1606$, found 351.1604. $R_{f}=0.33$ (hexane/EtOAc 3:1).

4.4. General procedure for the synthesis of $(Z)-1,2: 3,4-d i-O$ isopropylidene-9-C-phenyl-6,7,8,9-tetradeoxy- $\beta$-D-galactonona-6-en-8-ynopyranose ( $\boldsymbol{Z})$-7: A reaction flask containing the bromoalkene 3c (1.0 mmol, $334 \mathrm{mg}), \mathrm{PPh}_{3}(0.2 \mathrm{mmol}, 52 \mathrm{mg})$, $\mathrm{Pd}(\mathrm{OAc})_{2}(5.0 \mathrm{~mol} \%, 11 \mathrm{mg})$, and $\mathrm{CuI}(5.0 \mathrm{~mol} \%, 10 \mathrm{mg})$ was degassed and filled with argon. DMF $(5 \mathrm{~mL})$ and $i-\mathrm{Pr}_{2} \mathrm{NH}(2.5 \mathrm{~mL})$ were added followed by ethynylbenzene $(1.2 \mathrm{mmol}, 0.13 \mathrm{~mL})$. After stirring at room temperature for $10 \mathrm{~h}$, the mixture was diluted

* Corresponding author. Tel.: +34-985103499; e-mail: hrsolla@uniovi.es

\section{References and notes}

1 Stanforth, S. P. In Comprehensive Organic Functional Group Transformations II; Katritzky, A. R., Taylor, R. J., Eds.; Elsevier: Oxford, 2005; Vol. 2, p. 1025.

2 (a) Dixon, D. J.; Ley, S. V.; Gracza, T.; Szolcsany, P. J. Chem. Soc., Perkin Trans. 1 1999, 839-841. (b) Krishna Reddy, Y. Falck, J. R. Org. Lett. 2002, 4, 962-971.

3 Goekjian, P. G.; Wu, T.; Kang, H; Kishi, Y. J. Org. Chem. 1991, $56,6422-6434$.

4 Norsikian, S.; Soulé, J.-F.; Cannillo, A.; Guillot, R.; Tran Huu Dau, M.-E.; Beau, J.-M. Org. Lett. 2012, 14, 544-547.

5 Wnuk, S. F.; Sacasa, P. R.; Lewandowska, E.; Andrei, D.; Cai, S.; Borchardt, R. T. Bioorg. Med. Chem. 2008, 16, 5424-5433.

6 (a) Wnuk, S. F.; Yuan, C.; Borchardt, R. T.; Balzarini, J.; De Clercq, E.; Robins, M. J. J. Med. Chem. 1994, 37, 3579-3587. (b) Wnuk, S. F.; Robins, M. J. Can. J. Chem. 1993, 71, 192-198.

7 Okazoe, T.; Takai, K.; Utimoto, K. J. Am. Chem. Soc. 1987, 109, 951-953.

8 (a) Takai, K.; Nitta, K.; Utimoto, K. J. Am. Chem. Soc. 1986, 108, 7408-7410. (b) Evans, D. A.; Black, W. C. J. Am. Chem. Soc. 1993, 115, 4497-4513. (c) White, J. D.; Jackson, R. W.; Hanselmann, R. Chem. Commun. 1998, 79-80. (d) Kanda, Y.; Fukuyama, T. J. Am. Chem. Soc. 1993, 115, 8451-8452.

9 León, E. I.; Paz, N. R.; Riesco-Fagundo, C.; Suárez, E. Tetrahedron 2008, 64, 10706-10713.

10 Soengas, R. G; Silva, V. L. M.; Pinto, J.; Rodríguez-Solla, H.; Silva, A. M. S. Eur. J. Org. Chem. 2016, 99-107.

11 Concellón, J. M.; Rodríguez-Solla, H.; Simal, C.; Gómez, C. Synlett 2007, 75-78.

12 Concellón, J. M.; Bernad, P. L.; Bardales, E. Org. Lett. 2001, 3, 937-939. with $\mathrm{H}_{2} \mathrm{O}(8 \mathrm{~mL})$ and extracted with $\mathrm{Et}_{2} \mathrm{O}(5 \mathrm{~mL})$. The combined organic extracts were washed with $\mathrm{H}_{2} \mathrm{O}(5 \mathrm{~mL})$ and brine $(5 \mathrm{~mL})$, dried over $\mathrm{Na}_{2} \mathrm{SO}_{4}$, and concentrated to dryness. The resulting residue was purified by column chromatography (silica gel, hexane/EtOAc 8:1). Yellow oil, $[\alpha]_{\mathrm{D}}^{22}+5.2^{\circ}\left(\mathrm{c} 0.8, \mathrm{CHCl}_{3}\right)$, yield $92 \% .{ }^{1} \mathrm{H}$ NMR (300 MHz, $\mathrm{CDCl}_{3}$ ): $\delta 7.42-7.39(\mathrm{~m}, 2 \mathrm{H}), 7.33-7.26$ $(\mathrm{m}, 3 \mathrm{H}), 6.11(\mathrm{dd}, J 11.0,8.0 \mathrm{~Hz}, 1 \mathrm{H}, \mathrm{H}-8), 5.90(\mathrm{dd}, J 11.0,1.0$ $\mathrm{Hz}, 1 \mathrm{H}, \mathrm{H}-7), 5.58$ (d, J 5.0 Hz, $1 \mathrm{H}, \mathrm{H}-1), 5.01$ (dd, J 8.0, $2.0 \mathrm{~Hz}$, $1 \mathrm{H}, \mathrm{H}-5), 4.67$ (dd, J 7.9, $2.5 \mathrm{~Hz}, 1 \mathrm{H}, \mathrm{H}-3), 4.39-4.44$ (m, $2 \mathrm{H}$, H-2, H-4), 1.57 (s, $3 \mathrm{H}), 1.50$ (s, $3 \mathrm{H}), 1.35$ (s, $3 \mathrm{H}), 1.34$ (s, $3 \mathrm{H})$. ${ }^{13} \mathrm{C}$ NMR $\left(75 \mathrm{MHz}, \mathrm{CDCl}_{3}\right): \delta 138.7,131.4,128.4,128.3,122.9$, 111.4, 109.3, 108.9, 96.4, 95.1, 85.2, 73.2, 70.8, 70.3, 67.0, 26.1, 25.9, 25.0, 24.3. MS (ESI $\left.{ }^{+}-\mathrm{TOF}, m / z, \%\right): 357\left([\mathrm{M}+\mathrm{Na}]^{+}, 4\right), 241$ (100); HRMS (ESI ${ }^{+}$): calcd. for $\mathrm{C}_{21} \mathrm{H}_{25} \mathrm{O}_{5}[\mathrm{M}+\mathrm{H}]^{+} 357.1696$, found $357.1707 ; R_{f}=0.31$ (hexane/EtOAc 8:1).

\section{Acknowledgments}

Thanks are due to the Spanish Ministerio de Economía y Competitividad (CTQ2010-14959, CTQ2014-55015-P), for financial support. University of Aveiro and FCT/MEC for the financial support of the QOPNA research unit (FCTUID/QUI/00062/2013) through national funds and, where applicable, co-financed by the FEDER, within the PT2020 Partnership Agreement, and to the Portuguese NMR Network.

13 Concellón, J. M.; Rodríguez-Solla, H.; Simal, C.; Santos, D.; Paz, N. R. Org. Lett. 2008, 10, 4549-4552.

14 Concellón, J. M.; Rodríguez-Solla, H.; Simal, C.; Huerta, M. Org. Lett. 2005, 7, 5833-5835.

15 Concellón, J. M.; Rodríguez-Solla, H.; Huerta, M.; Pérez-Andrés. J. A. Eur. J. Org. Chem. 2002, 1839-1847.

16 Concellón, J. M.; Bardales, E. J. Org. Chem. 2003, 68, 9492-9495.

17 This fact can be explained as a consequence of the $n$-BuLi metalation of a C-I bond in diiodomethane; 1,2-addition of the in situ generated iodomethyl anion and further epoxidation of the iodomethyl alkoxide intermediate. 6,7-anhydro-1,2:3,4-di$O$-isopropylidene-D-glycero- $\beta$-D-galacto-heptopyranose: ${ }^{1} \mathrm{H}$ NMR (300 MHz, $\left.\mathrm{CDCl}_{3}\right): \delta 5.55(\mathrm{~d}, J 5.0 \mathrm{~Hz}, 1 \mathrm{H}, \mathrm{H}-1), 4.63$ (dd, J 7.9, $2.4 \mathrm{~Hz}, 1 \mathrm{H}, \mathrm{H}-3), 4.40$ (dd, J 7.9, $1.9 \mathrm{~Hz}, 1 \mathrm{H}, \mathrm{H}-$ 4), 4.34 (dd, $1 \mathrm{H}, J$ 5.0, 2.4 Hz, H-2), 3.46 (dd, 1H, J 6.3, 1.9 Hz, H-5), 3.23-3.27 (m, 1H, H-6), 2.89 (dd, 1H, J 5.2, 3.9 Hz, H-7b), 2.73 (dd, 1H, J 5.2, 2.6 Hz, H-7a), 1.50 (s, 6 H), 1.40 (s, $3 \mathrm{H}), 1.35$ (s, $3 \mathrm{H})$.

18 (a) Soengas, R. G.; Estévez, A. M. Eur. J. Org. Chem. 2010, 51905196. (b) Rodríguez-Solla, H.; Alvaredo N.; Soengas, R. G. Synlett 2012, 23, 2083-2086. (c) Soengas, R. G.; Estévez, A. M. Tetrahedron Lett. 2012, 53, 570-574. (d) Soengas, R. G.; Estévez, A. M. Synlett 2010, 2625-2627. (e) Soengas, R. G.; Estévez, A. M. Synlett 2012, 23, 873-876. (f) Soengas, R. G.; Silva, A. M. S. Tetrahedron 2013, 69, 3425-3431. (g) Soengas, R. G.; Acúrcio, R.; Silva, A. M. S. Org. Biomol. Chem. 2014, 12, 8593-8597.

19 Kasatkin, A. N.; Podlipchuk, L. P.; Biktimirov, R. K.; Tolstikov, G. A. Russ. Chem.Bull. 1993, 42, 1078-1082.

20 (a) Rodríguez-Solla, H.; Concellón, C.; Alvaredo, N.; Llavona, R.; Garcia-Granda, S.; Díaz, M. R.; Soengas, R. G. Synlett 2013, 24 , 181-184. (b) Soler, T.; Bachki, A.; Falvello, L. R.; Foubelo, F.; Yus, M. Tetrahedron: Asymm. 2000, 11, 493-517.

21 Concellón, J. M.; Rodríguez-Solla, H. Chem. Soc. Rev. 2004, 33, 599-609.

22 (a) Keck, G. E; Truong, A. P. Org. Lett. 2002, 4, 3131-3134. (b) Molander, G. A. Org. React. 1994, 46, 211-367. 